\title{
THE IMPACT OF KNOWLEDGE INDICATORS ON THE COUNTRY'S COMPETITIVENESS
}

\author{
Elena Širá ${ }^{1}$
}

DOI: https://doi.org/10.31410/ITEMA.S.P.2019.157

\begin{abstract}
Each economy contains a key resource that determines its economic growth. Knowledge is the main source in the knowledge economy. Its creation and use have a dominant share in wealth creation. However, it is not only a matter of deepening existing knowledge, but also of using it effectively and applying it to all economic activities. The aim of the paper is to determine, if the performance of the country in the area of knowledge economy influences its competitiveness. The knowledge economy will be evaluated through selected indicators, such as number of scientific publications and number of patents. To evaluate the competitiveness, were used the data from competitiveness ranking published by the World Economic Forum. The article investigated these indicators in the example of selected countries from the Europe. It assessed the dependence between the number of scientific publications per capita and the number of patent applications per capita.
\end{abstract}

Keywords: Knowledge Economy, Scientific Publications, Patents, Development.

\section{INTRODUCTION}

\subsection{Knowledge economy}

The knowledge economy, which is a part of the knowledge society, is the term umbrella of the economy of knowledge and the knowledge-based economy. The problem of the knowledge-based economy has become acute at the turn of the millennium, especially in the context of the lagging European countries against the US in competitiveness. The concept of knowledge society and economy does not have a fixed conceptual apparatus, the idea of knowledge society is based on the concept of information society. (Murgas, 2011)

The prerequisites for the emergence of knowledge-based economies according to Dudová (2011) are:

- a long-term trend of gradual growth in the weight of intangible capital on production factors,

- the emergence and growth of the diffusion of information and communication technologies - this factor underlying the emergence of the knowledge economy is based primarily on the fact that- communication technologies are a factor in accelerating the pace of innovation.

Knowledge is sometimes considered a fifth factor of production in the current economy and its generation plays a critical role in the firm's competitive advantage and its economic performance. (Rajnoha, Štefko, Merková, Dobrovič, 2016) The information society is increasingly transforming into a knowledge society, which is characterised by a mass access and use of knowledge. (Tomčíková, Bednárová, Naščáková, 2015) 
A successful transition to a knowledge-based economy is often based on the following four basic elements:

- long-term investment in education,

- innovative skills - their development,

- modernization of information infrastructure,

- creating a favourable economic environment. (Sundać, Krmpotić, 2011).

Other authors, e.g. Pukala and Koval (2017) added the next element, the government regulation. The World Bank has defined the following pillars of the knowledge economy:

1. economic incentives and the institutional system - this pillar provides an adequate economic policy and institutions that allow effective mobilization and resource allocation and stimulate creativity for the efficient creation, dissemination and exploitation of existing knowledge,

2. educated and skilled human resources - which can continuously be developed and they can adapt their skills to create and exploit knowledge effectively,

3. an effective business innovation system - this includes research centers, universities and consultants from other organizations that can keep pace with the knowledge „revolution", draw on growing knowledge stocks, master them and adapt them to local needs,

4. a modern and appropriate information and communication structure - which can make communication more efficient, as well as the dissemination and processing of information and knowledge (Chen, Dahlman, 2005).

\subsection{Competitiveness}

Competitiveness is a market feature to give the right to manage and assess the society resources primarily to those who use them most efficiently. In different economic or management encyclopedias and vocabularies, competition is described as a contention of producers and traders for better farming and goods' realisation conditions as well as for the entrench in the market, noting that competition stimulates culture development of economics and management and leads ineffectively working producers to bankruptcy. (Rutkauskas, 2008)

Competitiveness of national economies depends on competitiveness of enterprises, companies, competitiveness of regions and socio-economic conditions. (Mura et al., 2017) It represents the growth (Pirimova, 2017) of the country in the sphere of other countries' development. Innovations are a key factor for the competitiveness on national and business level. (Stoyanova, Sterev, 2018)

\section{METHODOLOGY}

The aim of the article is to determine, if the performance of the country in the area of knowledge economy influences its competitiveness. The knowledge economy will be evaluated through selected indicators. They are:

- the number of scientific publications,

- the number of patent applications.

To determine these set indicators, there were used other data from Eurostat, World Bank, World Economic Forum and other organisations. To evaluate the competitiveness, we have used the data from competitiveness ranking named the Global Competitiveness Index published every year. The period for evaluation the situation in mentioned countries was from 2009 to 2018. 
These countries were chosen for evaluation: Germany, France, Italy, Spain, Hungary and Slovakia. These countries were chosen according to the value of GDP per capita. Germany and France belong to the strong economies with the highest amount of GDP per capita from the selected countries. Italy and Spain gained the middle value of GDP per capita and Hungary and Slovakia were the weakest countries with the lowest values of this indicator. These selected countries also belong to almost all four groups of countries according to the Summary Innovation Index SII marked by Bobáková (2007).

\section{DISCUSSION}

An important output of scientific research is the quantity of scientific publications in peer-reviewed academic journals. Although there are more than 100,000 journals in the world, but only the part of them are indexed by world famous research databases. (Nguyen, Pham, 2011) Firstly, we have analysed the number of scientific publications per million inhabitants in selected countries. This indicator is very important for every knowledge economy, because it is focused on the value of research in a country.

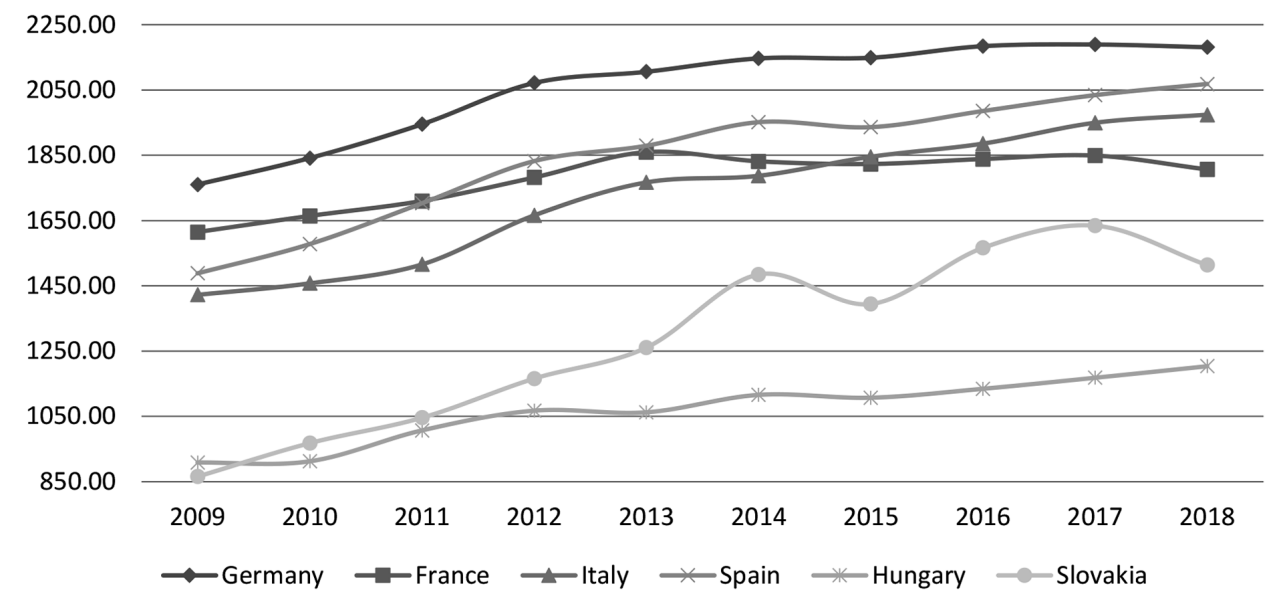

Graph 1. Number of scientific publications per million capita

Source: own calculations according to Scimago data

As one can see from the Graph 1, the highest number of this indicator was in Germany through the whole analysed period. There is the big gap between the best countries and the last one. But the positive information is, that in every analysed country, there was an increase in indicator level. The greatest increase was in the case of Slovakia in the analyzed period.

While patents reflect inventive and innovative activities that are proprietary in nature and developed mainly for commercial purposes, scientific literature informs mainly about the activities of the academic community. However, scientific literature has become more and more relevant for high-technology industries in the last few decades, and it is an important source of industrial competitiveness. (Archibugi, Coco, 2005)

The next analysed indicator of knowledge economy, the number of patents per million inhabitants is shown in the next graph. The development of this indicator in the years 2009 - 2017 was almost similar. Only in the Germany, there has been the decline in the stated values. In this indicator, there can be seen the cluster of 3-4 countries, with the similar values. Mainly, there are Slovakia, Hungary, Spain and maybe Italy. 


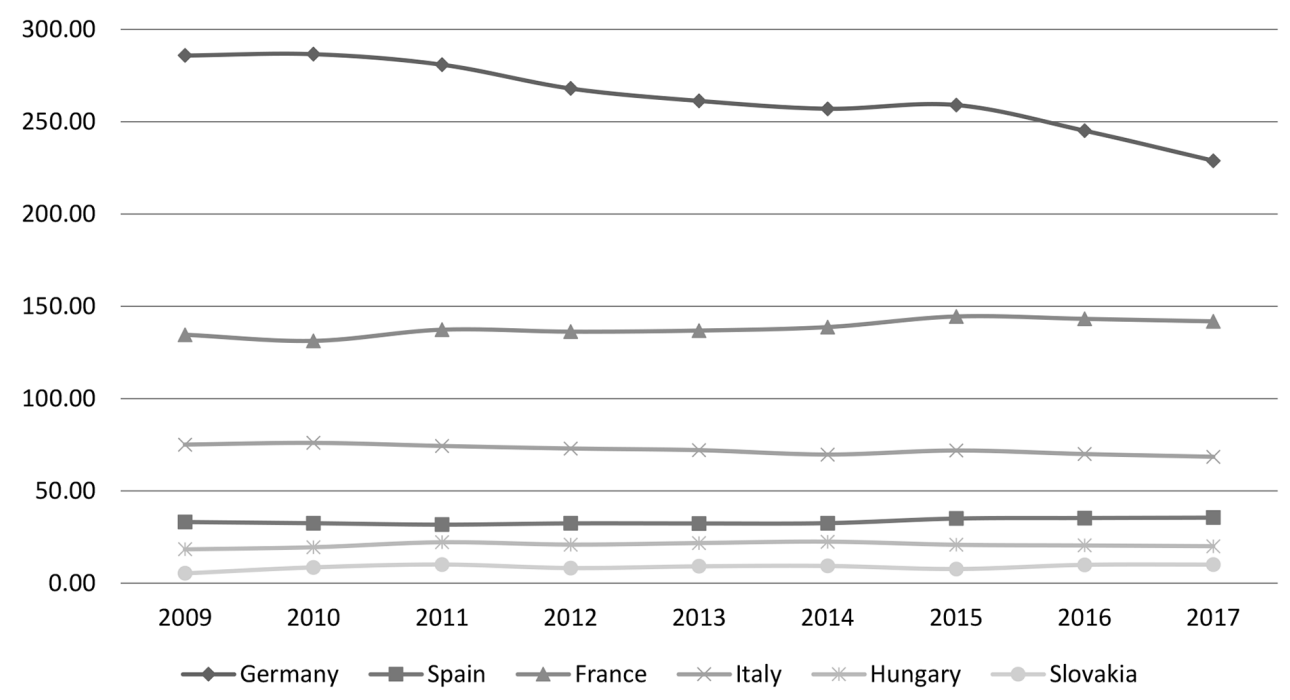

Graph 2. Number of patent applications per million capita

Source: own calculations according to Eurostat data

We will solve the hypothesis by means of a correlation coefficient, which determines the strength of the relationship among individual indicators, or variables, using the XY Scatterplot, which determines the linear dependence of the variables and ultimately their statistically significant dependence or independence through regression analysis. This analysis will be carried out through the Gretl statistical program.

Hypothesis: We assume a dependence between the number of scientific and technical publications per capita and the number of patent applications per capita.

Correlation coefficient: the value of the correlation coefficient based on the calculation of the Gretl program is: $r=-0.55450204$ which represents a great force of relationship between variables.

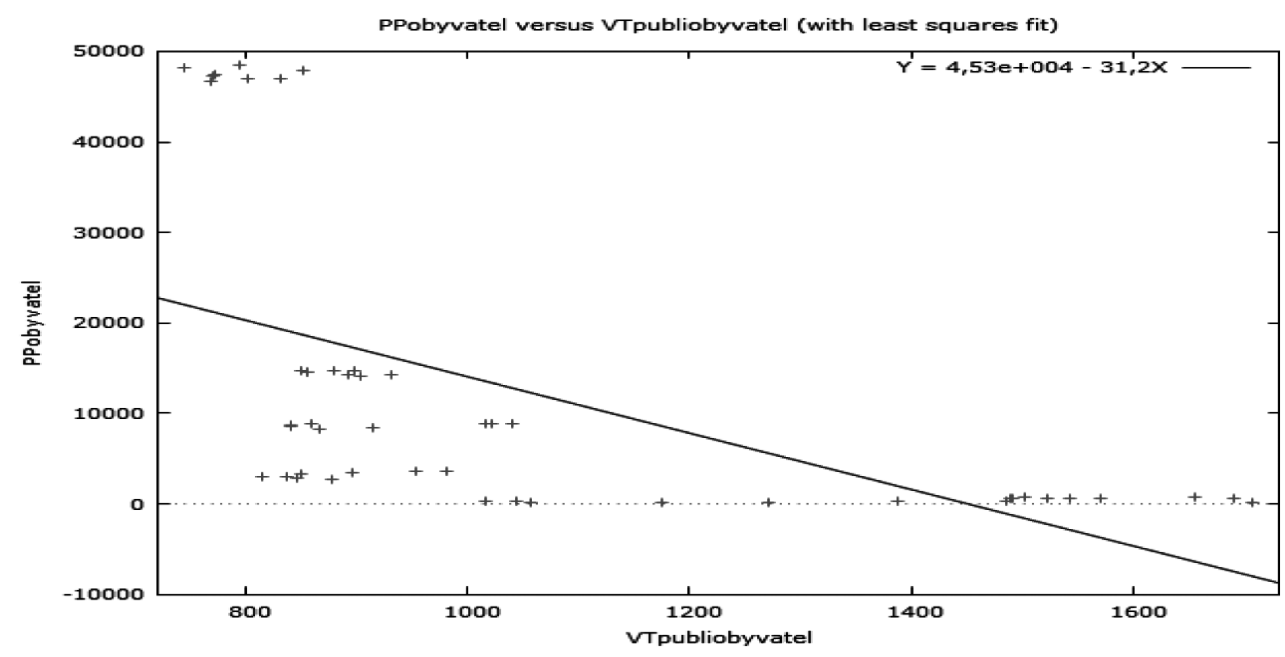

Graph 3. Hypothesis 1 - XY Scatterplot graph

Source: own processing via Gretl

On the basis of the above graph, there is an indirect link between the number of scientific and technical publications per capita and the number of patents per capita. 


\subsection{Regression analysis}

As the above hypothesis implies, we want to find out whether the number of patents per capita depends on the number of scientific and technical publications per capita. In this case, $y$ is a dependent variable and thus is per capita scientific and technical publications, and $\mathrm{x}$ is an independent variable, i.e. the number of patent applications per capita. There can be determined general model, the specific model and the estimated regression model:

General model: $\quad y_{i}=\alpha+\beta 1 \times l_{i}+u_{i}$

Specific model: $\quad$ scientific publications $=\alpha+\beta 1 \times$ number of patent applications $+u_{i}$

We set the hypotheses:

H0: $\beta=0$ holds if $\mathrm{p}<0.05$

H1: $\beta \neq 0$ applies if $p \geq 0.05$

where $\mathrm{H} 0$ speaks about the statistical significance of the coefficient $\beta$ and thus confirms the dependence between the variables, and H1 says that the coefficient $\beta$ is not statistically significant, therefore it says that there is no dependency between the variables.

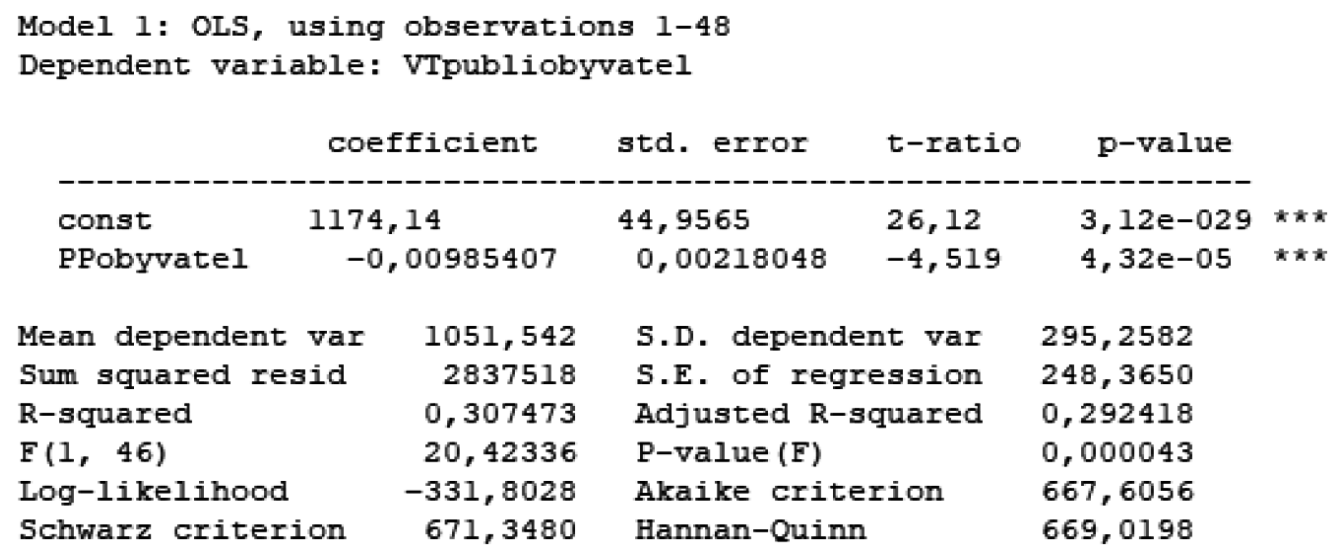

Graph 4. Hypothesis 1 - Regression model

Source: own processing via Gretl

\section{Estimated model:}

scientific publications $=1,174.14-0.0098 \times$ number of patent applications $+u_{i}$

A negative value of the coefficient $\beta$ confirms the indirect dependence between variables.

P-value: The $p$-value based on the Gretl program represents 0 , which implies $0<0.05$ thus $\mathrm{H} 0$ is rejected, $\mathrm{H} 1$ is accepted and thus $\beta$ is statistically significant and there is a statistically significant dependence between variables. 


\section{CONCLUSION}

In the case of the set indicators and countries' performance in it, we can say that there are differences between high developed countries and others. But the gap between them is small, and other countries for example Slovakia, has raised its performance in the number of scientific publications per million inhabitants very fast. According to statistical evaluation, we can state that there is a statistically significant dependence between both variables.

In the case of competitiveness in the GCI 2018, the Germany reached the 3rd place from 140 world economies. From our analyzed countries, it was the best position. Also, in the analyzed indicators, Germany obtained the highest values and during the analyzed period, it gained the best position. Hungary reached the lowest values in analyzed indicators as well as in GCI. Hungary ranked the worst position in GCI from the analyzed countries.

Table 1. Ranking of the countries according to GCI

\begin{tabular}{|l|l|}
\hline \multicolumn{1}{|c|}{ Country } & \multicolumn{1}{c|}{ GCI 2018 } \\
\hline Germany & 3rd place (82.8 score) \\
\hline France & 17th place (78 score) \\
\hline Spain & 26th place (74.2 score) \\
\hline Italy & 31st place (70.8 score) \\
\hline Slovakia & 41st place (66.8 score) \\
\hline Hungary & 48th place (64.3 score) \\
\hline
\end{tabular}

Source: own processing according to WE Forum

According to these results, we can say that the performance of the economy in the area of knowledge economy indicators predetermines economies to similar development of competitiveness.

There are many indicators, which can be placed into the group of knowledge economy indicators. So, their further analyses can bring new results and thus it can be a theme for further investigation.

\section{REFERENCES}

Archibugi, D., \& Coco, A. (2005). Is Europe becoming the most dynamic knowledge economy in the World? JCMS: Journal of Common Market Studies, 43(3), 433-459.

Bobáková, V., (2007). Inovačná výkonnost' ekonomiky. Zborník z medzinárodnej vedeckej konferencie SEMAFOR 2007-Ekonomika firiem, 44-51.

Chen, D. \& Dahlman,C. (2005). The Knowledge Economy, the KAM Methodology and World Bank Operations

Dudová, I. (2011). Ekonómia vzdelávania. Bratislava: Vydavatel’stvo EKONÓM. ISBN: 978-80225-3117-7.

Koval, V. \& Pukala, R. (2017). Implementation of regulatory policy in economic activity: development of the institute regulatory impact assessment. Економіка. Екологія. Соиіум, (1, вип. 1), 24-32.

Mura, L., Ključnikov, A., Tvaronavičienè, M., \& Androniceanu, A. (2017). Development trends in human resource management in small and medium enterprises in the Visegrad Group. Acta Polytechnica Hungarica, 14(7), 105-122.

Murgaš, F. (2011). Znalostná ekonomika, tacitné znalosti, spillovers znalostí a l’udský kapitál. RELIK, 1-9. 
Nguyen, T. V., \& Pham, L. T. (2011). Scientific output and its relationship to knowledge economy: an analysis of ASEAN countries. Scientometrics, 89(1), 107-117.

Pirimova, V. (2017). External determinants of growth in the Bulgarian economy In Recent Advances in Information Technology, Tourism, Economics, Management and Agriculture. Paper presented at International Scientific Conference ITEMA 2017, Budapest, October 26, 2017 (pp. 350-357). Belgrade: Association of Economists and Managers of the Balkans.

Rajnoha, R., Štefko, R., Merková, M., \& Dobrovič, J. (2016). Business intelligence as a key information and knowledge tool for strategic business performance management. $E+M$ Ekonomie a Management.

Rutkauskas, A. V. (2008). On the sustainability of regional competitiveness development considering risk. Technological and Economic Development of Economy, 14(1), 89-99.

Stoyanova, T. \& Sterev, N. (2018). Technology transfer as innovation driver for growth In V. Bevanda (Ed.), Recent Advances in Information Technology, Tourism, Economics, Management and Agriculture. Paper presented at $2^{\text {nd }}$ International Scientific Conference ITEMA 2018, Graz University of Technology, Graz, November 8, 2018 (pp.13-19). Belgrade: Association of Economists and Managers of the Balkans. https://doi.org/10.31410/itema.2018.125

Sundać, D. \& I. F. Krmpotić. (2011). Knowledge Economy Factors and the Development of Knowledge-based Economy. In Croatian Economic Survey

Tomčíková, M., Bednárová, L., \& Naščáková, J. (2015, November). The knowledge society and offer of qualified workers. In 2015 13th International Conference on Emerging eLearning Technologies and Applications (ICETA) (pp. 1-6). IEEE. 